ISSN: 1858-4837; E-ISSN: 2598-019X

Volume 17, Nomor 1 (2022),

https://jurnal.uns.ac.id/region

DOI: 10.20961/region.v1711.41904

\title{
Pemanfaatan Dana Desa bagi kegiatan usaha kecil menengah di Desa Wirokerten, Kecamatan Banguntapan, Kabupaten Bantul, Provinsi D.I. Yogyakarta
}

\author{
The utilization of Village Fund for small and medium enterprises in Wirokerten \\ Village, Banguntapan District, Bantul Regency, Special Region of Yogyakarta \\ Province
}

\author{
D I Arrosyid ${ }^{1}$ dan A M Sukmawati ${ }^{1}$ \\ ${ }^{1}$ Program Studi Perencanaan Wilayah dan Kota, Fakultas Sains dan Teknologi, \\ Universitas Teknologi Yogyakarta, Yogyakarta, Indonesia
}

Corresponding author's email: danindraiqbal44@gmail.com

\begin{abstract}
Abstrak. Dana Desa adalah dana yang bersumber dari Anggaran Pendapatan dan Belanja Negara yang diperuntukkan bagi desa untuk membiayai pelaksanaan kegiatan pemerintahan, pembangunan desa, pembinaan dan pemberdayaan masyarakat desa. Pemanfaatan Dana Desa di Desa Wirokerten digunakan untuk kegiatan pembangunan (70\%) dan pemberdayaan masyarakat (30\%). Di sisi lain, Desa Wirokerten juga memiliki ragam potensi Usaha Kecil dan Menengah (UKM) sehingga pengalokasian Dana Desa untuk UKM terus meningkat dari tahun ke tahun dengan jumlah persentase pertambahannya kurang lebih $9 \%$. Artikel ini bertujuan untuk menemukenali efektivitas pemanfaatan Dana Desa bagi kegiatan UKM di Desa Wirokerten. Penelitian menggunakan metode penelitian kualitatif dengan teknik analisis deskriptif kualitatif. Pengumpulan data dilakukan dengan teknik wawancara mendalam kepada 9 informan, observasi lapangan, dan dokumentasi. Temuan penelitian menunjukkan bahwa kegiatan UKM di Desa Wirokerten dikelola oleh Badan Usaha Milik Desa (BUMDes) Wirajaya Makmur. BUMDes ini mengelola beberapa kelompok UKM, seperti sentra emping melinjo, pengrajin sepatu rajut, pembuatan paving block, perkebunan hidroponik, dan pemilahan sampah. Pemanfaatan Dana Desa bagi kegiatan UKM belum efektif karena adanya permasalahan dalam partisipasi masyarakat. Kendala yang dihadapi adalah pola pikir masyarakat sulit diubah karena masih menjadikan pertanian sebagai mata pencaharian utama dan enggan beralih atau mencari penghasilan tambahan dari kegiatan lain. Selain itu, minimnya
\end{abstract}


pengalaman dan keterampilan anggota UKM untuk menemukan inovasi baru serta rendahnya keinginan untuk meneruskan program-program yang ada menyebabkan UKM menjadi kurang mandiri dan bergantung pada Dana Desa.

Kata Kunci: Dana Desa; Desa Wirokerten; Partisipasi Masyarakat; UKM

\begin{abstract}
Village fund is fund sourced from the State Revenue and Expenditure Budget which are intended for villages to finance the implementation of government activities, village development, fostering and empowering village communities. The village fund of Wirokerten Village is allocated for village development activities (70\%) and community empowerment (30\%). On the other hand, Wirokerten Village also has various Small and Medium Enterprises (SMEs), thus the allocation of village fund for SMEs continues to increase from year to year with a total percentage change of approximately $9 \%$. This article aims to find out the effectiveness of utilizing village fund for SMEs activities in Wirokerten Village. This study used qualitative research method with qualitative descriptive analysis technique. Data was collected using in-depth interview with 9 informants, field observations, and documentation. The findings show that SMEs activities in Wirokerten Village are managed by Village-Owned Enterprise (BUMDes) Wirajaya Makmur. This BUMDes manages several SMEs groups, such as emping melinjo center, knitting shoe craftsmen, paving block factories, hydroponic plantation, and waste sorting. The utilization of village funds for SMEs activities is less effective due to the problem in community participation. The main constraints are community's mindset which is difficult to alter since they still make agriculture as the main livelihood and are reluctant to shift or look for additional income from other activities. In addition, lack of experience and skills of SMEs members to discover new innovations and low eagerness to continue existing programs causes SMEs less independent and dependent on village funds.
\end{abstract}

Keywords: Community Participation; SMEs; Village Fund; Wirokerten Village

\title{
1. Pendahuluan
}

Dana Desa diartikan sebagai dana yang bersumber dari APBN yang diperuntukkan bagi desa yang ditransfer melalui Anggaran Pendapatan dan Belanja Daerah (APBD) [1]. Lebih lanjut, menurut UU No 32 Tahun 2004 [2], pemerintah memberikan kesempatan kepada masyarakat desa untuk mengatur dan mengurus rumah tangganya sendiri dengan persyaratan yang diamanatkan dalam undang-undang tersebut, yaitu diselenggarakan dengan memperhatikan prinsip-prinsip keadilan, peran serta masyarakat, pemerataan, keadilan, serta memperhatikan potensi dan keanekaragaman daerah. Untuk itu, Dana Desa merupakan bagian dari dana pemerataan pusat dan daerah yang dikhususkan untuk desa dalam mengimplementasikan layanan pemerintah dan pemberdayaan masyarakat dalam rangka meningkatkan kualitas hidup masyarakat desa.

Dana Desa diterima melalui perencanaan pembangunan pedesaan. Pengalokasian Dana Desa hendaknya mengacu pada Rencana Pembangunan Jangka Menengah Desa (RPJMDesa) dan 
rencana kerja pemerintah desa [3]. Pemanfaatan alokasi Dana Desa merupakan wujud desentralisasi bidang keuangan yang diberikan kepada pemerintah desa. Porsi alokasi Dana Desa yang diberikan menyesuaikan dengan program atau rencana kerja pemerintah desa yang peruntukannya dapat digunakan untuk pembangunan fisik dan pemberdayaan masyarakat. Dana Desa juga berpeluang untuk menurunkan tingkat kemiskinan. Hal ini dikarenakan Dana Desa memiliki manfaat, salah satunya yaitu untuk mengurangi ketimpangan pembangunan antardesa melalui optimalisasi pelayanan publik dan pengembangan potensi [4].

Namun demikian, implementasi penggunaan Dana Desa seringkali kurang optimal. Hal ini dikarenakan dalam pelaksanaan penggunaan Dana Desa tidak sesuai dengan kebijakan yang ada, sumber daya manusia sebagai pengelola Dana Desa yang masih belum memadai, pembangunan fasilitas dan infrastruktur yang belum terealisasi, dan minimnya partisipasi masyarakat. Menurut pendapat Asni [5] bahwa kemampuan pemerintah desa dalam manajemen keuangan berpengaruh dalam keberhasilan pengelolaan Dana Desa. Hal ini terkait dengan kemampuan perangkat desa dalam menyusun APBDes, perencanaan dan program pembangunan desa serta kemampuan administrasi lainnya $[6,7]$.

Padahal partisipasi masyarakat, modal sosial, dan peran kelembagaan pengelola menentukan efektivitas implementasi penggunaan Dana Desa [5,8,9]. Untuk itu, Dana Desa hendaknya tidak hanya dimaknai sebagai dana yang diberikan oleh pemerintah pusat kepada desa agar menjadi lebih otonom, namun juga dapat mendorong partisipasi masyarakat untuk terlibat dalam pembangunan [10]. Maka dengan adanya partisipasi dan pemberdayaan masyarakat dalam pemanfaatan Dana Desa, diharapkan akan mewujudkan desa yang kuat dan mandiri, yaitu desa yang mampu menentukan program prioritas untuk memenuhi kebutuhan lokal dan melaksanakan perencanaan desa sehingga mampu memecahkan masalah desa [11]. Partisipasi masyarakat juga bermanfaat untuk mengontrol penggunaan anggaran Dana Desa [12].

Penelitian ini mengambil lokasi di Desa Wirokerten, Kecamatan Banguntapan, Kabupaten Bantul, Provinsi Daerah Istimewa Yogyakarta. Desa Wirokerten memiliki luas wilayah sebesar 386,17 Ha dan terdiri dari delapan pedukuhan serta 75 RT. Adapun peta administrasi dan pembagian delapan dukuh di Desa Wirokerten terlihat di Gambar 1.

Desa Wirokerten memiliki beragam potensi, seperti desa wisata, pemancingan ikan bawal, obat herbal, serta Usaha Kecil dan Menengah (UKM). UKM di Desa Wirokerten tersebar di enam dukuh, yaitu di Kepuh Kulon, Wirokerten, Glondong, Mutilan, Grojogan dan Kepuh Wetan. UKM tersebut dikelola oleh BUMDes Wirajaya Makmur yang mengelola beberapa kelompok UKM, yaitu sentra emping melinjo, pengrajin sepatu rajut, pembuatan paving block, perkebunan hidroponik, dan pemilahan sampah.

Desa Wirokerten pertama kali mendapat alokasi Dana Desa pada tahun 2015. Kebijakan pengalokasian ini tercantum dalam Peraturan Bupati Bantul Nomor 29 Tahun 2015 Tentang Tata Cara Pengalokasian Dana Desa dan Besaran Dana Desa untuk Setiap Desa Tahun Anggaran 2015 [13]. Ketentuan besaran alokasi Dana Desa tertuang dalam peraturan bupati 
yang diperbarui setiap tahunnya. Adapun besaran alokasi Dana Desa di Desa Wirokerten tahun 2015 hingga 2019 terlihat di Gambar 2. Besaran Dana Desa yang diterima oleh setiap desa pada setiap tahun tidak sama karena tergantung pada kemampuan APBN yang kemudian mempengaruhi pengalokasiannya untuk APBDes.
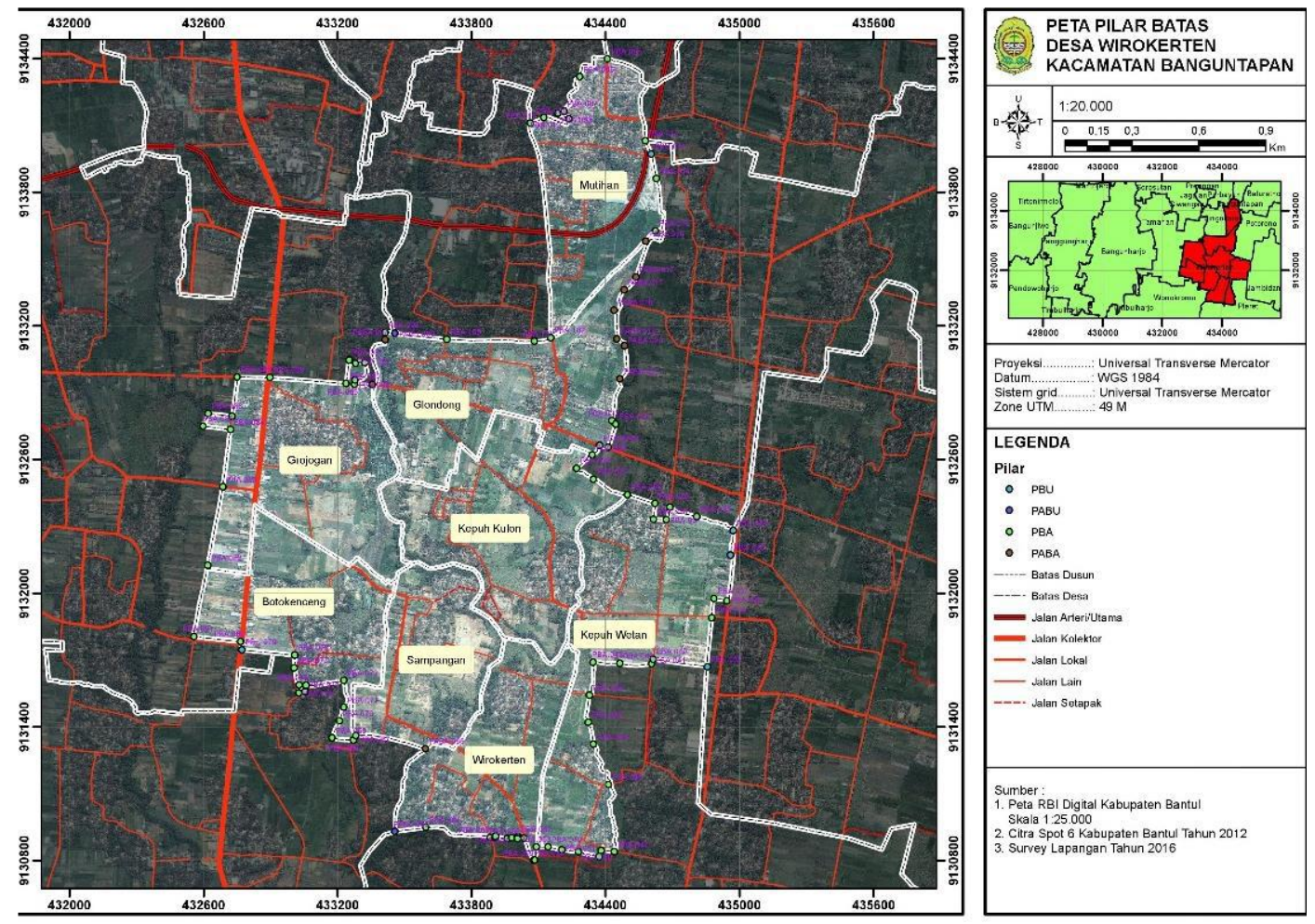

Gambar 1. Peta administrasi Desa Wirokerten.

Proporsi pengalokasian Dana Desa di Desa Wirokerten untuk kegiatan pembangunan fisik sekitar $70 \%$ dan pemberdayaan masyarakat sekitar $30 \%$. Fokus perencanaan dan sasaran Dana Desa di Desa Wirokerten tertuang dalam Rencana Kerja Pemerintah Desa (RKPDesa). RKPDesa ini menentukan arah perencanaan dan sasaran Dana Desa untuk satu tahun kedepan. Penyusunan RKPDesa mengacu pada fokus perencanaan Pemerintah Desa yang tertuang dalam RPJMDesa.

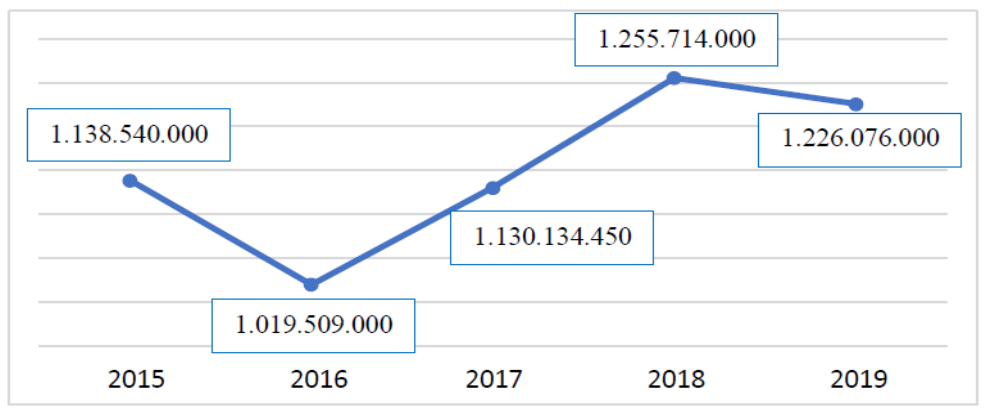

Gambar 2. Alokasi Dana Desa di Desa Wirokerten tahun 2015-2019 (dalam rupiah). 
Berdasarkan temuan Muslihah [14] mengenai pemanfaatan Dana Desa pada 75 desa di Kabupaten Bantul menunjukkan bahwa Dana Desa berdampak positif pada peningkatan kesejahteraan masyarakat. Dana Desa mampu meningkatkan penyerapan tenaga kerja melalui implementasi program-program yang bersumber dari Dana Desa. Namun, kondisi berbeda nampak terjadi di Desa Wirokerten. Meskipun UKM telah tersebar di hampir seluruh dukuh di Desa Wirokerten, namun Desa Wirokerten tergolong desa dengan tingkat kemiskinan tertinggi kedua di Kecamatan Banguntapan, yaitu 19\% dari total penduduk di Kecamatan Banguntapan. Grafik pada Gambar 3 menunjukkan persentase jumlah penduduk miskin di Kecamatan Banguntapan. Kondisi ini mengindikasikan bahwa penyerapan Dana Desa bagi aktivitas pemberdayaan masyarakat, khususnya untuk kegiatan UKM belum optimal.

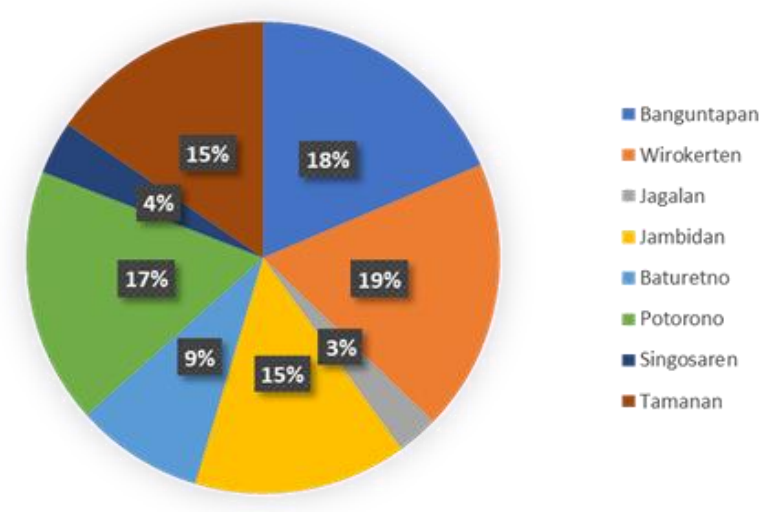

Gambar 3. Jumlah penduduk tergolong miskin per desa di Kecamatan Banguntapan [15].

Dana Desa di Desa Wirokerten dialokasikan untuk beberapa kegiatan, seperti pelatihan UKM, pelatihan KWT dan Gapoktan, bantuan alat, dan fasilitasi promosi pameran produk di Bantul Expo. Tulisan ini berfokus pada pengalokasian Dana Desa bagi kegiatan UKM. UKM di Desa Wirokerten disinyalir belum mampu sepenuhnya meningkatkan perekonomian masyarakat serta mendorong keterlibatan masyarakat di dalamnya. Terdapat beberapa kendala atau hambatan yang mungkin mempengaruhi implementasi alokasi Dana Desa untuk pengembangan UKM di Desa Wirokerten. Padahal Dana Desa yang dialokasikan bagi Desa Wirokerten memiliki besaran yang cenderung meningkat, meskipun proporsi untuk kegiatan pemberdayaan masyarakat masih kecil (sekitar 30\%). Berdasarkan permasalahan tersebut, penelitian ini bertujuan untuk menemukenali efektivitas pemanfaatan Dana Desa bagi kegiatan UKM di Desa Wirokerten.

\section{Metode}

Metode penelitian yang digunakan adalah metode penelitian kualitatif dengan pendekatan studi kasus. Metode penelitian kualitatif adalah penelitian yang bertujuan untuk menggali informasi secara mendalam serta membangun makna terhadap suatu fenomena/kejadian berdasarkan pandangan dari para informan [16]. Adapun pendekatan yang digunakan dalam penelitian ini adalah pendekatan studi kasus. Creswell [16] mendefinisikan pendekatan studi kasus dapat digunakan untuk mengevaluasi dan menganalisis mendalam suatu program, 
peristiwa, aktivitas dalam kurun waktu tertentu sehingga kasus dibatasi oleh aktivitas dan waktu.

Metode penelitian kualitatif dengan pendekatan studi kasus dipilih karena penelitian bertujuan untuk menemukenali efektivitas pemanfaatan Dana Desa di Desa Wirokerten dengan time frame lima tahun terakhir (2015-2019), yaitu sejak Desa Wirokerten menerima Dana Desa untuk pertama kali pada tahun 2015 hingga tahun terakhir saat data penelitian didapatkan, yaitu data tahun 2019. Adapun tahapan penelitian studi kasus yang dilakukan terlihat pada bagan di Gambar 4.

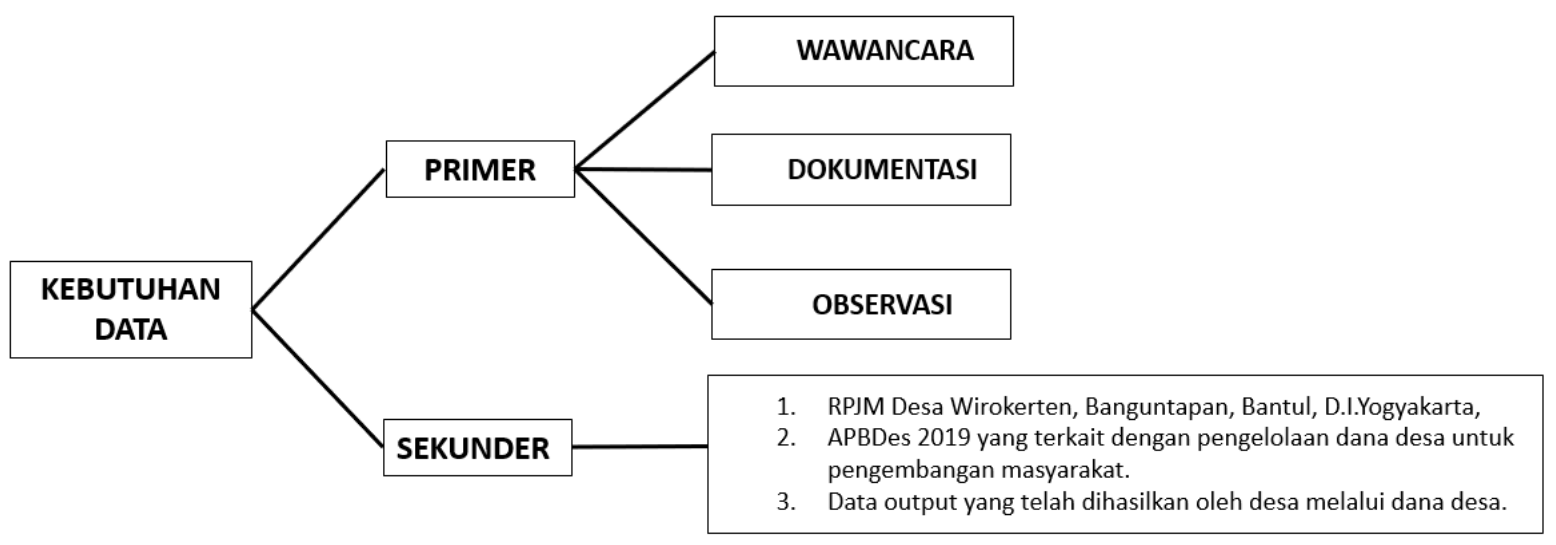

Gambar 4. Bagan dalam tahapan proses pendekatan studi kasus.

Penelitian dilakukan dengan metode pengumpulan data primer dan sekunder. Metode pengumpulan data primer yang digunakan adalah wawancara mendalam (in-depth interview), observasi lapangan, dan dokumentasi. Wawancara mendalam dilakukan dengan teknik purposive sampling dan snowball sampling dengan total jumlah informan sebanyak sembilan informan, meliputi perangkat desa, ketua BUMDes, ketua Gapoktan, ketua KWT, dan pelaku UKM. Wawancara difokuskan untuk menggali informasi mengenai persebaran lokasi UKM, kinerja UKM dari tahun ke tahun, kinerja penggunaan Dana Desa, dampak pemanfaatan Dana Desa bagi UKM, dan faktor penghambat pemanfaatan Dana Desa untuk pemberdayaan masyarakat, khususnya UKM. Observasi lapangan dan dokumentasi dilakukan ke beberapa UKM, seperti UKM pengrajin sepatu rajut di Dusun Glondong, UKM emping melinjo di Dusun Kepuh Kulon, UKM pembuatan paving block di Dusun Mutilan, perkebunan hidroponik di Dusun Wirokerten, UKM pemilahan sampah yang berada di Dusun Kepuh Wetan untuk mengamati dan mendokumentasikan kondisi fisik dari lokasi UKM serta keberlangsungan kegiatan UKM. Sementara itu, metode pengumpulan data sekunder dilakukan dengan telaah dokumen kebijakan perencanaan desa, seperti RPJMDesa dan APBDesa serta berbagai literatur terkait dengan studi.

Analisis dilakukan dengan teknik analisis deskriptif kualitatif yang berupaya untuk memberikan penjelasan informasi secara mendalam mengenai objek pengamatan dengan menggunakan data deskriptif. Miles \& Hubberman [17] menjelaskan teknik analisis data 
kualitatif pada umumnya terdiri dari beberapa tahap, yaitu reduksi data, penyajian data, dan verifikasi data. Adapun aplikasi tahapan teknik analisis data kualitatif pada penelitian ini terjelaskan di Gambar 5. Pada tahap awal reduksi data, peneliti melakukan transkripsi hasil wawancara untuk menuangkan keseluruhan informasi yang didapatkan. Setelah itu, informasi yang relevan diberi kode (coding) dengan format (Nama informan/tanggal wawancara/nomor urut baris pada transkrip wawancara), kemudian dikelompokan atau dikategorikan berdasarkan tema-tema tertentu. Pada tahap penyajian data, informasi disajikan secara deskriptif dan didukung oleh tabel, grafik, dan peta-peta untuk memperjelas deskripsi. Sementara itu, untuk menguji keabsahan/validitas hasil penelitian digunakan teknik triangulasi sumber data dengan cara mengecek informasi yang telah diperoleh melalui beberapa sumber, yaitu wawancara, observasi, dan telaah dokumen.

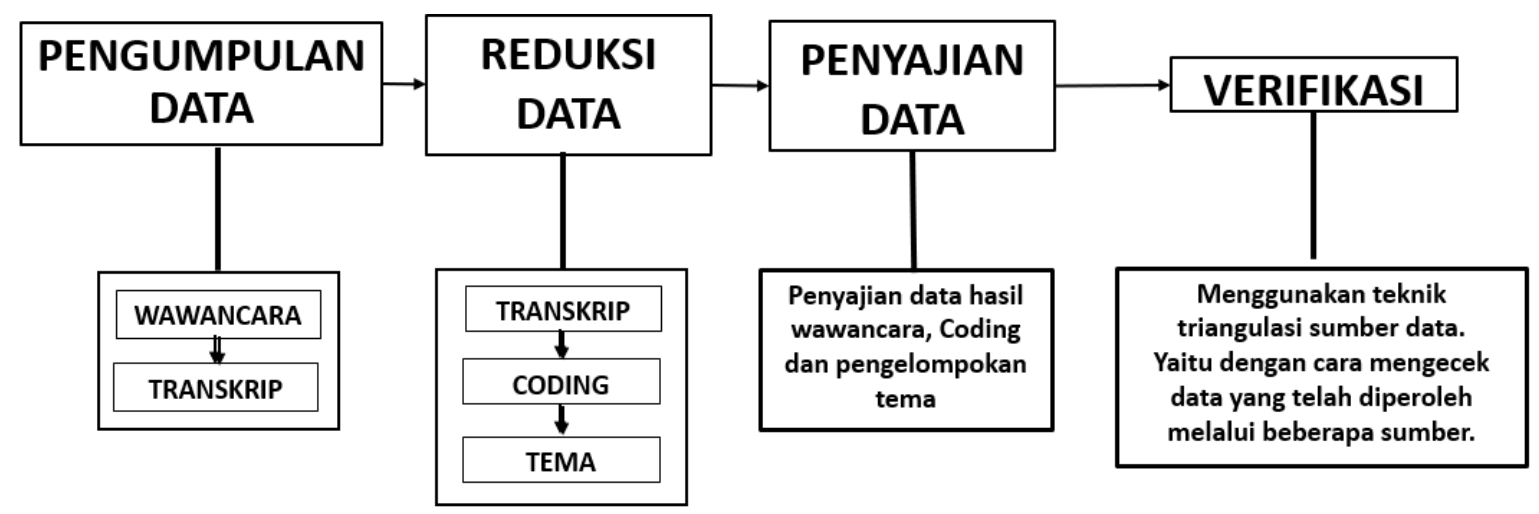

Gambar 5. Proses teknik analisis data kualitatif.

\section{Hasil penelitian dan pembahasan}

\subsection{Profil UKM di Desa Wirokerten}

Desa Wirokerten memiliki lima jenis UKM yang tersebar di enam dukuh sehingga secara total terdapat delapan kelompok UKM di Desa Wirokerten. Kelima jenis UKM tersebut, meliputi emping melinjo, pengrajin sepatu rajut, pembuatan paving block, perkebunan hidroponik, dan pemilahan sampah. Lokasi persebaran delapan kelompok UKM di Desa Wirokerten terlihat di Gambar 6.

UKM pengrajut sepatu terdapat di Dusun Glondong. Kegiatan UKM masih berlangsung di rumah warga karena belum memiliki tempat sendiri untuk keberlangsungan kegiatan UKM. Hasil produksi tersebut berupa kerajinan sepatu rajut, sandal rajut, sepatu rajut anak-anak, sandal/sepatu wanita, dan sebagainya yang masih menggunakan tangan. Hasil kerajinan sepatu rajut terlihat di Gambar 7a. Selain itu, terdapat juga alat untuk memintal benang tetapi sebagian besar proses produksinya masih menggunakan tangan atau manual sehingga pemberdayaan masyarakat diperlukan dalam proses produksi sepatu rajut. Namun, keterlibatan masyarakat masih terbatas. Anggota tetap pengrajut sepatu hanya 10 orang sedangkan anggota tidak tetap kurang lebih delapan orang. 


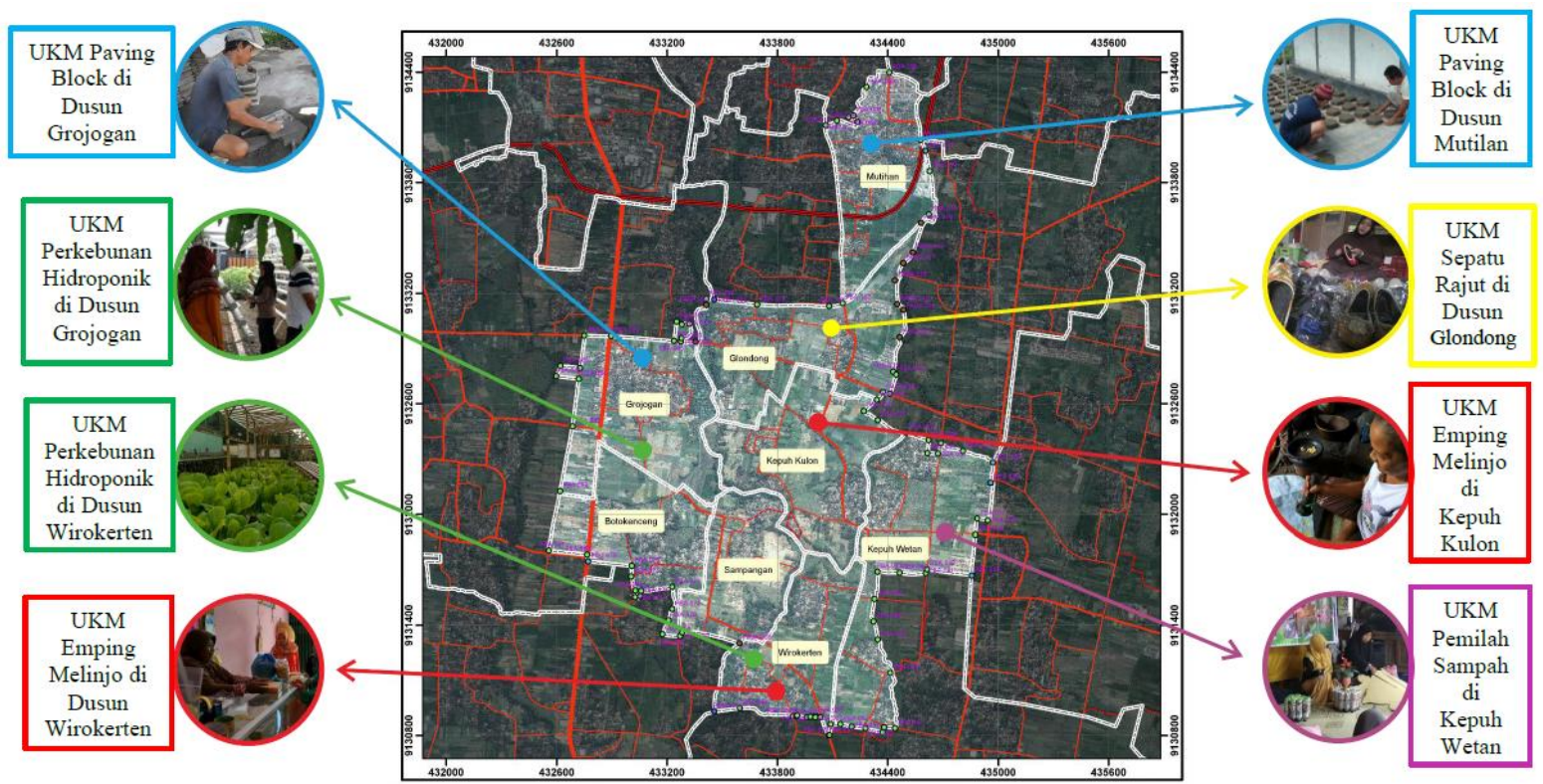

Gambar 6. Persebaran UKM di Desa Wirokerten.

UKM emping melinjo memiliki level produksi skala rumahan. Jenis kegiatan pemberdayaan masyarakat yang dilakukan adalah aktivitas produksi dengan menggunakan alat berupa alas besi dan pemukul emping, dan berbahan baku buah melinjo yang masih dikerjakan secara manual. Hasil produksi emping melinjo tersebut akan dijual juga di ruko/toko sekitar tempat UKM yang memproduksi emping melinjo (lihat Gambar 7b). UKM emping melinjo memiliki pekerja tetap sebanyak delapan orang dan pekerja tidak tetap kurang lebih 16 orang. Hasil produksinya berupa emping melinjo manis (besar), emping melinjo pedas (besar), emping melinjo manis (kecil), dan emping melinjo pedas (kecil).

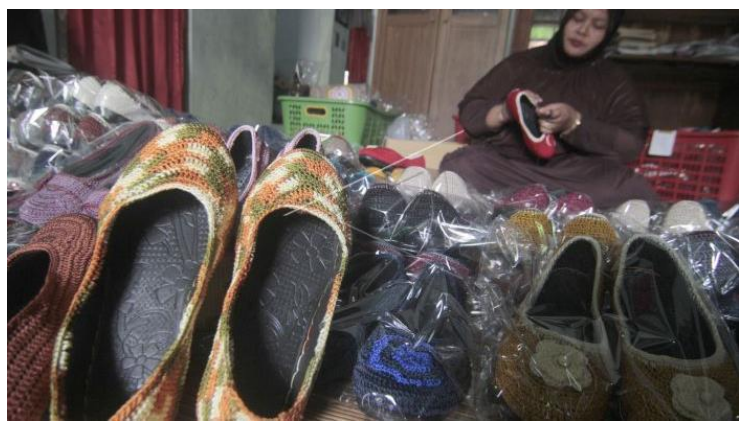

(a)

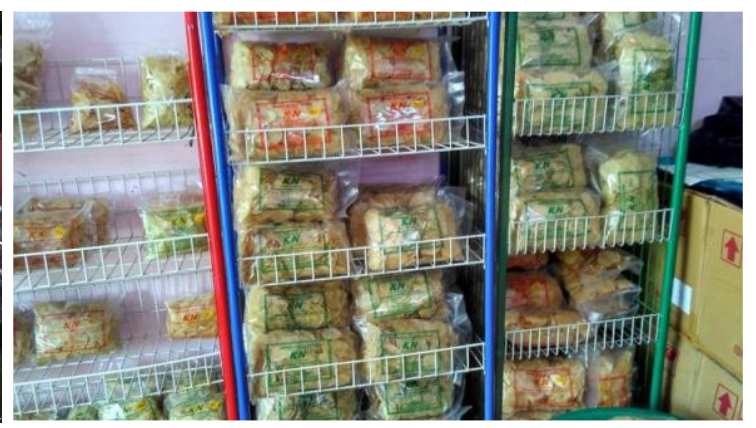

(b)

Gambar 7. (a) Hasil kerajinan sepatu rajut di Dusun Glondong, (b) Hasil UKM sentra emping melinjo di Dusun Kepuh Kulon.

UKM pembuatan paving block dilakukan di sebuah bangunan semi permanen yang dimiliki oleh BUMDes Wirajaya Makmur. Luas lahan yang digunakan kurang lebih sebesar $25 \mathrm{~m}^{2}$. Jenis kegiatan pemberdayaan masyarakat berupa produksi beragam bentuk paving block dengan menggunakan alat berupa besi cetak dan berbahan baku semen, pasir dan kerikil yang masih 
dilakukan dengan tenaga manusia. Jumlah pekerja tetap di UKM pabrik paving block sebanyak 15 orang dan pegawai tidak tetap sekitar 20 orang. Hasil produksi dari UKM paving block adalah beragam bentuk paving block yang dapat digunakan untuk pembangunan jalan, taman, perumahan, dan sebagainya.

UKM perkebunan hidroponik berlangsung di sebuah lahan yang dimiliki oleh BUMDes Wirajaya Makmur. Jenis kegiatan yang dilakukan adalah kegiatan perkebunan sayuran hidroponik, seperti sawi, cabai, bayam, brokoli dan seledri. Jumlah masyarakat yang terlibat dalam kegiatan hidroponik kurang lebih sekitar 30 orang. Masyarakat terlibat dalam seluruh proses, mulai dari pembibitan, penanaman benih, perawatan tanaman, pemupukan, dan pemanenan.

Terakhir, UKM pemilahan sampah di Dusun Kepuh Wetan dilakukan di sebuah bangunan permanen. Bangunan permanen digunakan untuk pengumpulan sampah plastik yang sudah dipilah oleh warga masyarakat Desa Wirokerten. Jenis kegiatan yang dilakukan adalah pemilahan sampah plastik yang bisa didaur ulang dan bisa diolah menjadi kerajinan, seperti tas, taplak meja, dan lainnya. Adapun jumlah masyarakat yang terlibat dalam UKM ini sekitar 45 orang.

\subsection{Analisis pemanfaatan Dana Desa untuk kegiatan UKM}

3.2.1. Alur pengajuan dan fokus sasaran Dana Desa. Alur pengajuan Dana Desa di Desa Wirokerten berasal dari Pemerintah Pusat yang dialirkan melalui Pemerintah Kabupaten Bantul. Sebelum itu, Pemerintah Desa Wirokerten menyusun terlebih dahulu Rencana Kerja Pemerintah Desa (RKPDesa). Fokus perencanaan yang tertuang dalam RKPDesa ini mengacu pada program-program yang dimuat dalam Rencana Pembangunan Jangka Menengah Desa (RPJMDesa). RPJMDesa dan RKPDesa tersebut akan menjadi satu-satunya dokumen perencanaan desa untuk penyusunan APBDesa yang diatur melalui Peraturan Desa. Selanjutnya disesuaikan dengan program pembangunan Pemerintah Kabupaten, pemerintah kota serta dari pemerintah provinsi. Tidak hanya itu, mengingat pentingnya RKPDesa maka dibutuhkan peran dari Pemerintah Desa untuk dapat merancang program-program yang menjadi prioritas pembangunan setahun ke depan. Setelahnya RKPDesa disusun untuk diajukan ke Badan Permusyawaratan Desa (BPD). Setelah BPD mencermati RKPDesa tersebut melalui Musrembang, BPD dapat menyetujui RKPDesa dan Pemerintah Desa dapat mengajukan ke Pemerintah Kabupaten. Untuk itu, pengalokasian Dana Desa menyesuaikan dengan program-program yang dicantumkan dalam RKPDesa.

Keuangan desa tertuang dalam APBDesa yang merupakan rencana keuangan tahunan Pemerintah Desa yang dibahas dan disetujui oleh Pemerintah Desa dan Badan Permusyawaratan Desa (BPD) dan ditetapkan dalam peraturan desa (Perdes). Dana Desa merupakan bagian dari keuangan desa yang bersifat seperti hibah/bantuan keuangan yang diberikan oleh Pemerintah Pusat kepada Pemerintah Desa melalui undang-undang tentang desa. Pemerintah Pusat menempatkan desa sebagai ujung tombak pembangunan dan peningkatan kesejahteraan masyarakat. Desa diberikan kewenangan dan diberikan sumber 
dana untuk menjalankan kewenangannya dan meningkatkan ekonomi serta kesejahteraan masyarakat. Setiap tahunnya, Dana Desa yang diterima oleh setiap desa tidak sama. Pengalokasian APBDes untuk Dana Desa tergantung dari kemampuan Anggaran Pendapatan dan Belanja Negara (APBN). Perhitungan pengalokasian Dana Desa berpatokan pada Peraturan Pemerintah (PP) Nomor 60 tahun 2014 [1]. Namun saat ini, PP Nomor 60 tahun 2014 telah diganti dengan PP Nomor 22 tahun 2015 [18].

Peruntukkan Dana Desa di Desa Wirokerten memiliki sasaran untuk pembangunan kurang lebih $70 \%$ dan untuk pemberdayaan masyarakat kurang lebih 30\%. Namun demikian, persentase peruntukkan Dana Desa untuk kegiatan pemberdayaan masyarakat di Desa Wirokerten dari tahun ke tahun bertambah jumlahnya. Hal ini dikarenakan, pada tahun 2018 sasaran Dana Desa di Desa Wirokerten mulai berkonsentrasi untuk pemberdayaan masyarakat.

Bantuan Dana Desa khususnya untuk pemberdayaan masyarakat di Desa Wirokerten berfokus pada pengembangan BUMDes, pelatihan UKM (Usaha Kecil dan Menengah), Gapoktan, KWT (Kelompok Wanita Tani), bantuan alat, dan fasilitasi promosi pameran produk di Bantul Expo. Sedangkan untuk pengelolaan BUMDes, bersumber dari Dana Desa yang sudah dialokasikan dari RPJMDes dan APBDes pada tahun yang bersangkutan. Sementara itu, saat ini Dana Desa dikelola oleh beberapa lembaga, yaitu BUMDes, Gapoktan, KWT (Kelompok Wanita Tani), dan LPMD (Lembaga Pemberdayaan Masyarakat Desa). Hal tersebut disampaikan oleh beberapa informan mengenai fokus sasaran Dana Desa pada tahun 2019 berikut.

“Untuk lembaga khususnya pemberdayaan masyarakat itu ada Gapoktan, KWT (Kelompok Wanita Tani), LPMD (Lembaga Pemberdayaan Masyarakat Desa) dan BUMDes Wirajaya Makmur mas [19]."

“Dana Desa masih banyak untuk pembangunan di fisik kemarin mas, yang di nonfisik itu masuknya ke pendidikan, modal, pelatihan, dan kesehatan dan sebagainya. Untuk pemberdayaan masyarakat sendiri kita baru hanya pemberian modal awal, pelatihan dan pemberian alat saja mas, kita baru mulai berfokus ke pemberdayaan masyarakat mulai tahun 2018 kemarin mas. Kita masih dominan untuk pembangunan fisik tapi untuk persentase pemberdayaan masyarakat itu dari tahun ke tahun itu bertambah mas jumlahnya. Kalau sekarang konsentrasinya memang untuk pemberdayaan masyarakat, mas [20]."

"Prioritas desa masih dominan untuk pembangunan fisik tapi setiap tahun untuk persentase pemberdayaan masyarakat semakin bertambah mas. Untuk pemberdayaan kita berfokus pada BUMDes, pelatihan UKM, Gapoktan dan KWT, bantuan alat dan fasilitasi promosi pameran produk di Bantul Expo mas [21]."

3.2.2. Fokus Dana Desa untuk kegiatan UKM. Desa Wirokerten memiliki delapan kelompok UKM, yaitu UKM emping melinjo di Dusun Wirokerten dan Kepuh Kulon, UKM pembuatan paving block di Dusun Grojogan dan Muntilan, UKM pemilahan sampah di Dusun Kepuh 
Wetan, UKM sepatu rajut di Dusun Glondong, dan UKM hidroponik di Dusun Grojogan dan Wirokerten. Fokus kegiatan Dana Desa untuk pemberdayaan masyarakat, khususnya di bidang UKM disalurkan melalui lembaga desa, BUMDes Wirajaya Makmur (lihat Gambar 8). Bantuan yang diberikan berupa bantuan modal awal, bantuan peralatan produksi, biaya dan skill pelatihan, dan fasilitasi dalam pameran Bantul Expo. Bantuan-bantuan tersebut bermanfaat untuk membantu meningkatkan perekonomian masyarakat.

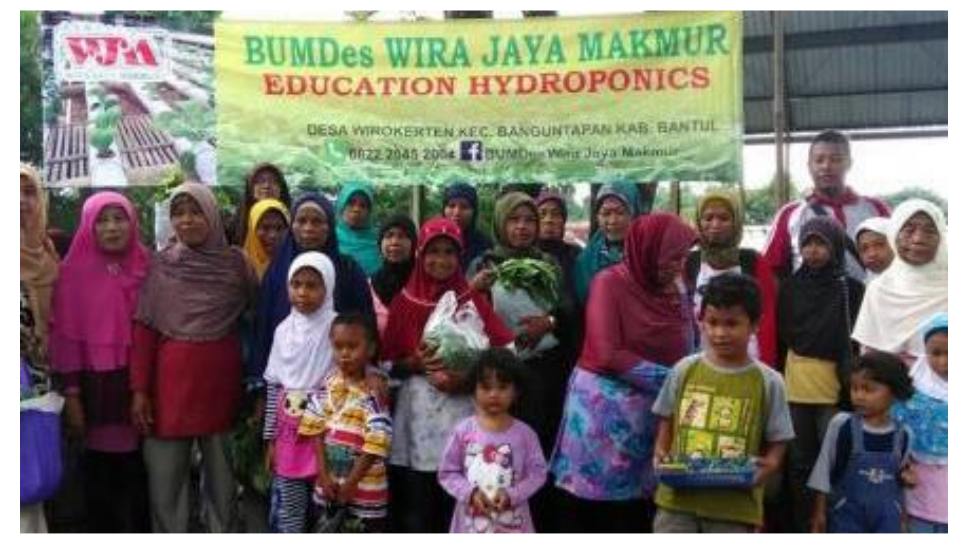

Gambar 8. BUMDes Wirajaya Makmur saat mendampingi pelatihan hidroponik di Desa Wirokerten.

Jenis UKM yang menjadi unggulan di Desa Wirokerten adalah UKM emping melinjo. Ini dikarenakan hasil produk dari UKM emping melinjo telah berhasil diproduksi dan dipasarkan keluar daerah serta pernah dipamerkan dalam Bantul Expo. Hasil produksi emping melinjo tersebut juga dipasarkan pada ruko atau toko di sekitar lokasi produksi UKM emping melinjo sehingga cakupan pemasarannya meluas.

"Kalau untuk kegiatannya kita melakukan pelatihan UKM-UKM dek, UKM-nya ada banyak di sini ada UKM pemilahan sampah, UKM pengrajin sepatu rajut, UKM pabrik paving block, desa wisata, pemancingan ikan bawal, obat herbal, UKM perkebunan hidroponik, UKM sentra emping melinjo. BUMDes juga memberikan modal awal untuk UKM-UKM tersebut dek, jadi kita memberikan bantuan modal awal, terus pelatihan, lalu kita juga memberikan alat produksi untuk memproduksi UKM itu dek [22]."

"Untuk UKM kita berikan bantuan berupa pelatihan, bantuan alat dan memfasilitasi pameran di Bantul Expo. Untuk hasil produknya UKM-nya banyak sekali kalau di sini, ada sentra emping melinjo, pengrajin sepatu rajut, pabrik paving block, perkebunan hidroponik, pemilahan sampah, pemancingan ikan bawal dan obat herbal [23]."

"Dalam alokasi Dana Desa untuk BUMDes tahun kemarin untuk modal, pelatihan dan penataan modal alat saja kemarin mas. Untuk kegiatannya, yaitu pelatihan UKM yang dinaungi BUMDes, mas [20]." 
Jika dilihat dari keterlibatan masyarakat dalam kegiatan UKM, anggota yang terlibat dalam UKM tersebut adalah kurang lebih 20 orang per UKM. Oleh karena itu, jika terdapat delapan UKM maka anggota yang terlibat keseluruhan berjumlah kurang lebih 160 orang. Hal tersebut dikarenakan terdapat anggota yang tidak tetap, yang mana terkadang ikut kegiatan UKM tersebut tetapi terkadang juga tidak mengikuti. Maka dapat dikatakan bahwa anggota tidak tetap hanya terlibat saat dibutuhkan.

"Ada 8 UKM di bawah naungan BUMDes dek, ada desa wisata, pemancingan ikan bawal, UKM obat herbal, UKM pemilahan sampah, UKM pengrajin sepatu rajut, UKM pabrik paving block, UKM perkebunan hidroponik, UKM sentra emping melinjo. Kalau paling dominan, kita ada UKM empling melinjo dek. Untuk anggotanya kurang lebih sekitar 20 orang per UKM, kalau 8 UKM ya berarti 160an orang, kita juga ada anggota tidak tetap kadang ikut gabung kadang tidak, biasanya anggota tidak tetap itu masyarakat di sekitar itu yang mempunyai mata pencaharian petani. Jadi, kalau ada pesanan yang ada dipanggil untuk mengerjakan, kadang ada yang berhalangan juga jadi memang tidak terdaftar [22]."

"UKM yang paling dominan masih sentra emping melinjo sama pengrajin sepatu rajut dek di Desa Wirokerten ini. Sekitar 20 orang per UKM dek, jadi kalau 8 UKM ya tinggal dikalikan saja 8 dikali 20 jadi 160-an orang jumlahnya, soalnya kan tidak tetap dek orang-orangnya, kadang ikut gabung kadang tidak, jadi kalau ada pesanan yang ada yang dipanggil untuk mengerjakan, kadang ada yang berhalangan, jadi tidak tetap [24]."

Jika dilihat secara kuantitas, jumlah anggota ini masih tergolong kecil. Hal ini dikarenakan tidak semua masyarakat tertarik untuk bergabung menjadi anggota UKM dikarenakan fokus pada mata pencaharian sebagai petani dan buruh tani. Grafik pada Gambar 9 memperlihatkan mayoritas mata pencaharian penduduk di Desa Wirokerten sebagai petani.

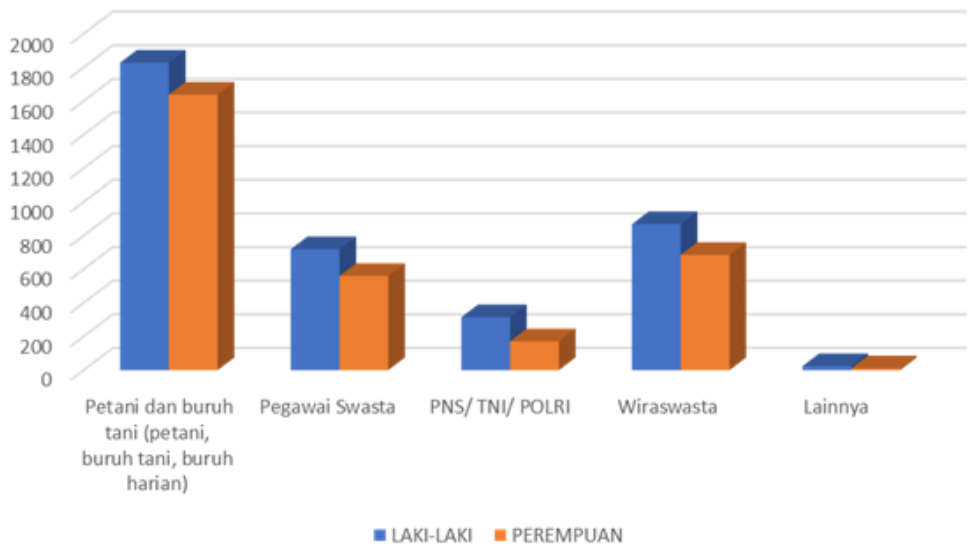

Gambar 9. Mata pencaharian penduduk di Desa Wirokerten [17].

3.2.3. Dampak pemanfaatan Dana Desa. Dana Desa yang diberikan memiliki manfaat pada aspek ekonomi dan sosial masyarakat. Dana Desa di Desa Wirokerten dialokasikan untuk 
beberapa kegiatan, seperti pelatihan KWT dan Gapoktan, pelatihan UKM, bantuan modal awal dan peralatan, dan fasilitasi pameran saat Bantul Expo. Namun, pada tulisan ini Dana Desa difokuskan pada pengelolaan Dana Desa bagi UKM.

Hasil wawancara menunjukkan bahwa Dana Desa yang diberikan belum sepenuhnya dapat berkontribusi positif bagi peningkatan kesejahteraan masyarakat Desa Wirokerten. Beberapa hal yang menjadi kendala, di antaranya yaitu pola pikir masyarakat yang belum bisa berpikir maju dan enggan keluar dari "zona nyaman" terhadap mata pencahariannya sebagai petani atau buruh tani. Sebagian besar masyarakat masih menjadikan pertanian sebagai sumber penghasilan utama dan enggan beralih maupun mencari sumber penghasilan tambahan. Kegiatan UKM bagi sebagian besar anggota yang juga berprofesi sebagai petani hanya digeluti ketika ada pesanan dan akan kembali menjadi petani saat pesanan telah selesai. Padahal, kegiatan UKM yang beragam di Desa Wirokerten berpeluang untuk meningkatkan perekonomian masyarakat jika digeluti dengan lebih seksama. Selain itu, penyebab lainnya karena kegiatan UKM juga merupakan jenis kegiatan pemberdayaan masyarakat yang notabene memerlukan waktu cukup lama untuk dapat melihat manfaat yang dihasilkan. Berbeda dengan perkembangan fisik yang dapat langsung dirasakan manfaatnya sehingga dampak sosial dan ekonomi dari UKM belum begitu signifikan dirasakan.

"Karena kurangnya keaktifan masyarakat, terus kurangnya kesadaran untuk lebih maju dari masyarakat, masyarakatnya yang masih susah untuk diajak berkembang [19]."

"Sampai saat ini yang sudah berhasil, yaitu pelatihan kelompok tani wanita, Gapoktan, pelatihan hidroponik, pengolahan sampah. Tetapi dalam hal BUMDes, saat ini sudah berjalan tetapi belum berjalan dengan baik karena belum ada dana operasional awal. Selain itu, pengurusnya juga sudah sepuh-sepuh sehingga kurang produktif untuk mencari profit/keuntungan. Mereka membuat paving block atau kerajinan kalau ada pesanan saja, jika tidak ada pesanan yang kembali menjadi petani atau mata pencaharian sebelumnya [23]."

"Faktor internal lebih ke kualitas sumber daya manusia, masyarakatnya yang masih susah untuk diajak berkembang, hanya satu dua saja yang mau diajak untuk berusaha dan berkembang. Hanya segelintir masyarakat saja, tidak semuanya aktif mas. Padahal setiap kita mau adakan kegiatan dalam hal pengelolaan Dana Desa, kita adakan sosialisasi mas, kalau masyarakat setuju ya lanjut, kalau masyarakat rasanya kurang setuju ya kita ganti dengan kegiatan yang lain. Terutama di masyarakat sekitar yang mau diadakan kegiatan tersebut [20]."

"Kalau menurut saya ya karena memang masyarakat di sini masih susah untuk diajak berkembang dek, masih enak di zona nyaman, ya kalau pekerjaannya sudah enak, kalau hanya buruh tani ya kan kasihan, tapi ya kita masih berusaha untuk merubah mindset pola pikir masyarakat untuk diajak berkembang [24]." 
Bagi UKM yang telah ada saat ini, UKM masih bergantung pada bantuan pemodalan dan peralatan yang diberikan oleh desa. UKM yang ada masih belum cukup mandiri untuk melaksanakan aktivitas produksinya. Terdapat keterbatasan kreativitas dan partisipasi masyarakat dalam mengelola dan mengembangkan UKM sehingga kegiatan-kegiatan peningkatan kapasitas UKM masih sangat bergantung dengan ketersediaan Dana Desa. Selain itu, juga masih rendahnya keterampilan dan tingkat pendidikan anggota UKM dalam mengembangkan UKM. Kondisi ini sesuai dengan latar belakang pendidikan masyarakat di Desa Wirokerten yang didominasi oleh tamatan SD sebesar 19\% dan SMA sebesar $26 \%$ seperti yang terlihat pada grafik di Gambar 10. Meskipun pihak desa telah berupaya mengalokasikan Dana Desa untuk peningkatan kapasitas UKM, namun partisipasi dari para anggota untuk melaksanakan dan meneruskan masih rendah.

"Kalau menurut saya faktor-faktornya, yaitu masyarakat yang belum gerak aktif untuk mau diajak bekembang dari program-program yang ada mas [25]."

"Karena kalau untuk pemberdayaan masyarakat sendiri, kalau kita mengadakan pemberdayaan masyarakat tetapi pola pikir masyarakatnya masih rendah ya percuma, kita latih dan sudah menggelontorkan dana yang cukup besar, tetapi setelah mendapatkan pelatihan tidak mau mengerjakan dan meneruskan untuk melanjutkan, karena belum ada niat dan pola pikir yang belum berkembang dari masyarakat. Jadi kita harus membentuk pola pikirnya dulu [23]."

"Ya itu tadi dek pola pikir masyarakat yang belum berkembang. Soalnya kita sudah sering mengadakan pelatihan tetapi masyarakat masih tidak mau melanjutkan kegiatan tersebut ya mau gimana lagi dek. Kita mengadakan pemberdayaan masyarakat tetapi pola pikir masyarakatnya masih rendah ya percuma, kita latih dan sudah menggelontorkan dana yang cukup besar, tetapi setelah mendapatkan pelatihan tidak mau mengerjakan dan meneruskan untuk melanjutkan ya sama saja. Karena belum ada niat tersendiri dari masyarakat [24]."

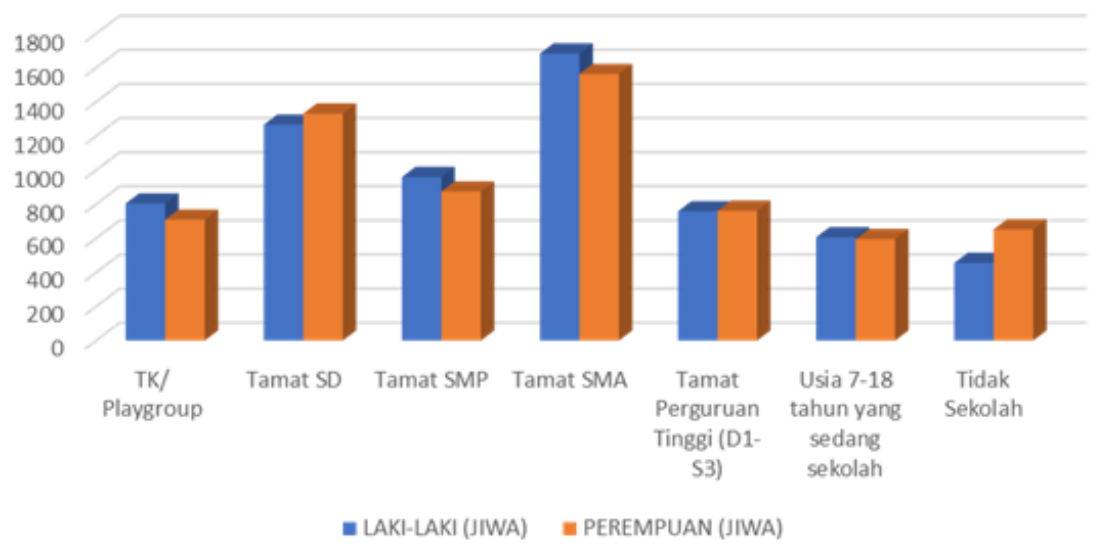

Gambar 10. Latar belakang pendidikan masyarakat di Desa Wirokerten [17]. 
Sebagaimana hasil wawancara dengan pengelola BUMDes Wirajaya Makmur dan pemerintah desa bahwa keberadaan Dana Desa di Desa Wirokerten belum efektif termanfaatkan untuk kegiatan pemberdayaan masyarakat, khususnya untuk pengembangan UKM. Hal ini dikarenakan beberapa ukuran keberhasilan penyelenggaraan berdasarkan keberhasilan penggunaan Dana Desa, seperti meningkatnya perekonomian masyarakat, usaha/ UKM bisa berjalan dengan mandiri tanpa bantuan dari Pemerintah Desa, sering mengikuti pameran dan promosi yang masif, serta menghasilkan profit/keuntungan untuk keluarga masing-masing belum dirasakan oleh masyarakat. Keberlanjutan program-program UKM juga diragukan untuk bisa berlanjut. Meskipun dari segi pendanaan pemerintah desa terus menggelontorkan Dana Desa untuk peningkatan kapasitas UKM, namun dari segi partisipasi masyarakat belum maksimal.

"Ya bisa dikatakan belum efektif mas, tetap dana anggaran untuk pemberdayaan masyarakat kita naik terus mas tiap tahun, anggarannya ada kenaikan untuk alokasi ke pemberdayaan masyarakat maupun pembinaan tapi ya gitu mas untuk masalah inovasi dan kesadaran masyarakat itu yang masih kurang [20]."

"Kalau dikatakan belum ya memang belum berhasil secara keseluruhan. Kurang berhasilnya karena memang biaya operasionalnya tidak ada sehingga keaktifan masyarakat yang memang masih kurang. Ya memang ada satu dua kelompok warga masyarakat yang sudah menjalankan UKM ini dengan rutin dan menjadikan kegiatan ini sebagai mata pencaharian, tetapi tidak banyak dek [24]."

\subsection{Diskusi: pemanfaatan Dana Desa untuk UKM}

Pengalokasian Dana Desa di Desa Wirokerten telah berjalan sesuai prosedur. Pengalokasian dimulai dengan adanya musrenbangdes yang dituangkan dalam RKPDesa. Jika dilihat dari segi besaran Dana Desa dari tahun ke tahun, Dana Desa juga cenderung meningkat dari tahun ke tahun meskipun pada tahun 2019 lalu mengalami penurunan dibandingkan tahun 2018. Selain itu, juga telah ada keinginan dari pemerintah desa untuk menambah proporsi penggunaan Dana Desa untuk kegiatan pemberdayaan masyarakat dan memperkecil proporsi untuk anggaran pembangunan fisik.

Meskipun anggaran Dana Desa untuk pemberdayaan masyarakat meningkat, namun menghadapi kendala pada inovasi dan kesadaran masyarakat untuk terlibat dalam kegiatan UKM. Beberapa faktor yang menjadi penyebabnya adalah pola pikir masyarakat yang sulit diubah karena enggan beralih profesi atau mencari sumber penghasilan tambahan dari mengelola UKM. Masyarakat masih menjadikan petani atau buruh tani sebagai mata pencaharian utama. Hal ini disebabkan kurangnya keterampilan dan tingkat pendidikan masyarakat sehingga mengurangi minat masyarakat untuk bergabung menjadi anggota UKM sehingga menghambat perkembangan UKM.

Menurut Boedijono [26], Dana Desa dikatakan efektif untuk kegiatan pemberdayaan masyarakat apabila terjadi perkembangan perekonomian warga desa. Hal ini ditandai oleh adanya bantuan peralatan bagi UMKM dan pelaku usaha, perluasan lapangan pekerjaan, 
pelatihan dan pembinaan bagi masyarakat untuk mengembangkan usaha, serta akses infrastruktur yang baik. Lebih lanjut, menurut Zakariya [27] bahwa Dana Desa seharusnya juga mampu mendorong peningkatan ekonomi masyarakat melalui pemberian soft infrastructure, seperti akses pendidikan dan kesehatan. Berdasarkan kondisi tersebut, maka diketahui bahwa pemanfaatan Dana Desa untuk kegiatan UKM di Desa Wirokerten belum efektif. Hal ini dikarenakan Dana Desa belum memberikan manfaat optimal bagi peningkatan ekonomi masyarakat. Hanya segelintir masyarakat yang sudah merasakan dampak Dana Desa bagi peningkatan ekonomi masyarakat, yaitu masyarakat atau anggota yang aktif berkegiatan di dalam UKM dan mendapatkan manfaat dari program-program, seperti pelatihan dan peningkatan keterampilan. Apabila dilihat dari dampak ekonomi, pemanfaatan Dana Desa belum memberikan peningkatan yang signifikan karena pola pikir masyarakat yang masih belum berubah. Meskipun Dana Desa telah digelontorkan cukup besar, namun setelah mendapatkan pelatihan para pelaku usaha kurang memiliki niat untuk melanjutkan. Selain itu, juga terkendala oleh masalah inovasi, kesadaran masyarakat untuk mau berkembang, dan keaktifan masyarakat. Namun demikian, pemerintah desa akan lebih berupaya untuk memberikan sosialisasi terhadap UKM dan pelatihan-pelatihan serta mengubah pola pikir masyarakat Desa Wirokerten.

Jika disandingkan dengan Instrumen Pendataan Profil Desa Wirokerten tentang penggunaan Dana Desa di Desa Wirokerten, Kecamatan Banguntapan, temuan kondisi di Desa Wirokerten juga sama-sama menunjukkan hasil yang belum efektif [28]. Hal tersebut disebabkan oleh kurangnya respon masyarakat untuk mau terlibat dalam program-program pemberdayaan. Namun demikian, tidak semua desa di Kabupaten Bantul belum optimal untuk memanfaatkan Dana Desanya. Seperti penelitian Atmojo [29] tentang penggunaan Dana Desa untuk pengembangan ekonomi berbasis masyarakat di Desa Bangunjiwo, Kabupaten Bantul yang sudah sangat efektif. Partisipasi masif dari masyarakat desa, terutama saat musrenbangdes untuk memberikan usulan program pembangunan desa, kritik pelaksanaan serta adanya inisiatif pemerintah desa untuk menggerakkan masyarakat menjadikan pemanfaatan Dana Desa menjadi efektif atau optimal. Dampak Dana Desa dapat dirasakan oleh seluruh elemen masyarakat untuk meningkatkan kondisi ekonomi.

Upaya untuk mengoptimalkan pemanfaatan Dana Desa agar manfaatnya dapat dirasakan banyak pihak, maka diperlukan langkah untuk mendorong partisipasi masyarakat seperti inisiasi dari pemerintah untuk mendorong keikutsertaan masyarakat dalam pembangunan desa. Hal ini dapat ditempuh dengan memprioritaskan program-program terkait dengan peningkatan perekonomian lokal, mengubah pola pikir pemimpin desa, dan membuka mindset masyarakat melalui peran dari tokoh-tokoh masyarakat bahwa upaya meningkatkan kesejahteraan merupakan usaha bersama sedangkan dana pemerintah terbatas sehingga perlu integrasi peran dari berbagai pihak [30].

Selain mendorong partisipasi masyarakat, juga diperlukan upaya dari pemerintah daerah untuk mewujudkan tata kelola pemerintahan yang baik (good governance). Hal ini dikarenakan dalam pelaksanaan penggunaan Dana Desa juga diperlukan kemampuan 
pengelola untuk memberikan pelaporan. Sosialisasi tentang penggunaan Dana Desa juga diperlukan disini, agar masyarakat mengetahui dan tertarik untuk terlibat menggunakannya. Oleh karena itu, perlu peningkatan kualitas dan kompetensi SDM aparatur desa sebagai pengelola Dana Desa secara administratif dan untuk pelaporan serta transparansi penggunaan Dana Desa [14,31]. Pengelolaan keuangan desa harus dilakukan berdasarkan tata kelola pemerintahan yang baik (good governance). Hal yang menjadi perhatian penting dalam good governance dan mencapai desa yang otonom, yaitu transparansi dan akuntabilitas [32]. Serupa dengan pendapat Hambali [33] bahwa untuk meningkatkan produktivitas ekonomi melalui Dana Desa diperlukan upaya untuk meningkatkan kapasitas institusi desa dan kelompok usaha serta melibatkan berbagai aktor untuk upaya tersebut, yaitu akademisi, pemerintah, dan pelaku usaha. Maka, dalam upaya mencapai efektivitas penggunaan Dana Desa dalam pengembangan kegiatan UKM, Pemerintah Desa Wirokerten perlu untuk melakukan beberapa hal, meliputi: 1) Meningkatkan kualitas dan kuantitas pelayanan publik; 2) Menciptakan ruang yang lebih luas bagi masyarakat untuk berpartisipasi dalam proses pembangunan dan pengembangan potensi ekonomi; 3) Meningkatkan pemberdayaan ekonomi masyarakat desa dalam rangka peningkatan kapasitas masyarakat agar lebih mandiri dan memiliki nilai tambah penghasilan; 4) Meningkatkan kualitas sumber daya manusia guna meningkatkan dan memperkuat produktivitas serta daya saing; dan 5) Meningkatkan pembangunan hard dan soft infrastructure pedesaan untuk meningkatkan aksesibilitas masyarakat.

\section{Kesimpulan}

Pemanfaatan Dana Desa untuk kegiatan UKM di Desa Wirokerten belum efektif. Meskipun memiliki banyak potensi UKM, namun keberadaan UKM tersebut belum mampu mengubah citra Desa Wirokerten sebagai salah satu desa dengan tingkat kemiskinan tertinggi di Kecamatan Banguntapan, Kabupaten Bantul. Hal ini dikarenakan karena terdapat kendala, yaitu aspek partisipasi masyarakat. Berdasarkan segi partisipasi masyarakat, Desa Wirokerten dihadapkan pada kendala minimnya keterlibatan masyarakat dalam program-program UKM yang diinisiasi dengan menggunakan Dana Desa, sulitnya mengubah pola pikir masyarakat yang masih mengandalkan mata pencaharian menjadi buruh tani, dan UKM yang ada saat ini masih bergantung pada lembaga pemberdayaan dari segi pendanaan sehingga sulit berkembang. Tidak hanya itu, manfaat Dana Desa untuk kegiatan pemberdayaan masyarakat membutuhkan waktu yang lebih lama untuk dapat dirasakan manfaatnya dibandingkan untuk kegiatan pembangunan fisik. Kondisi ini menjadikan dampak ekonomi belum signifikan dirasakan oleh masyarakat Desa Wirokerten. Berdasarkan hasil penelitian ini, maka penelitian selanjutnya diarahkan untuk menemukan strategi yang dapat mengoptimalkan pengelolaan Dana Desa bagi pemberdayaan ekonomi masyarakat di Desa Wirokerten dengan fokus pada menggugah partisipasi masyarakat.

\section{Referensi}

[1] Republik Indonesia. Peraturan Pemerintah Nomor 60 Tahun 2014 Tentang Dana Desa yang Bersumber Dari Anggaran Pendapatan dan Belanja Negara 2014.

[2] Republik Indonesia. Undang-Undang No 32 Tahun 2004 Tentang Pemerintah Daerah 
2004.

[3] Wibowo GA. Evaluasi Pengelolaan Alokasi Dana Desa Untuk Pembangunan Sarana Prasarana Desa (Desa Wonoasri Kecamatan Grogol Kabupaten Kediri). J Pembang Wil Kota 2017;13:313-25. https://doi.org/10.14710/mkmi.\%v.\%i.1-19.

[4] Artino A, Juanda B, Mulatsih S. Keterkaitan Dana Desa Terhadap Kemiskinan di Kabupaten Lombok Utara. Tataloka 2019;21:381-9. https://doi.org/10.14710/tataloka.21.3.381-389.

[5] Asni F, Maryunani, Sasongko, Budi D. The Management of the Village Fund Allocation as an Instrument towards Economic Independence Village (Case Studies in 2 villages in Siak Regency, Province Riau). IOSR J Bus Manag 2013;10:1-9.

[6] Yulita R, Mashur D. Efektivitas Pelaksanaan Penggunaan Alokasi Dana Desa (ADD) di Desa Setako Raya Kecamatan Peranap Kabupaten Indragiri Hulu. J Online Mhs Fak IImu Sos Dan Ilmu Polit 2016;3:1-13.

[7] Sofiyanto M, Mardani RM, Salim MG. Pengelolaan Dana Desa Dalam Upaya Meningkatkan Pembangunan Di Desa Banyuates Kecamatan Banyuates Kabupaten Sampang. J Ris Manaj 2017;6:28-38.

[8] Isti DN, Komar O, Heryanto N. Persepsi Dan Partisipasi Masyarakat Terhadap Pemanfaatan Dana Desa Untuk Pemberdayaan Masyarakat Di Desa Kertajaya Kecamatan Padalarang Kabupaten Bandung Barat. J Pendidik Luar Sekol 2016;13:5262.

[9] Tahili MH, Haning MT. Strengthening the Capacity of Village Government in the Implementation of Village Fund Policy at Maros Regency of South Sulawesi Province. Proc. 2018 Annu. Conf. Asian Assoc. Public Adm. "Reinventing Public Adm. a Glob. World A Non-Western Perspect. Ser. Adv. Soc. Sci. Educ. Humanit. Res., vol. 191, 2018, p. 383-91. https://doi.org/10.2991/aapa-18.2018.36.

[10] Dewi DAS, Syafingi HM, Aji AB. Paradigma Aparatur Desa dalam Penggunaan Dana Desa untuk Pemberdayaan Masyarakat. Pandecta Res Law J 2018;13:139-49. https://doi.org/10.15294/pandecta.v13i2.16020.

[11] Margayaningsih DI. Peningkatan Pemberdayaan dan Kemandirian Desa dalam Rangka Otonomi Daerah. J Publiciana 2015;8:164-91.

[12] Syamsi S. Partisipasi masyarakat dalam mengontrol penggunaan anggaran dana desa. JISIP J IImu Sos Dan Ilmu Polit 2014;3:21-8.

[13] Pemkab Bantul. Peraturan Bupati Bantul Nomor 29 Tahun 2015 tentang Tata Cara Pengalokasian Alokasi Dana Desa dan Besaran Dana Desa untuk Setiap Desa Tahun Anggaran 20152015.

[14] Muslihah S, Siregar HO, Sriniyati. Dampak Alokasi Dana Desa Bagi Pembangunan Daerah Dan Kesejahteraan Masyarakat. J Akuntansi, Ekon Dan Manaj Bisnis 2019;7:85-93. https://doi.org/10.30871/jaemb.v7i1.1027.

[15] BPS Kabupaten Bantul. Data Terpadu Program Penanganan Fakir Miskin Kecamatan Banguntapan. Bantul: Badan Pusat Statistik Kabupaten Bantul; 2017.

[16] Creswell JW. Research Design Pendekatan Metode Kualitatif, Kuantitatif, dan Campuran. Yogyakarta: Pustaka Belajar; 2017.

[17] Miles MB, Huberman AM. Analisis Data Kualitatif Buku Sumber Tentang Metode- 
Metode Baru. Jakarta: UI Press; 1992.

[18] Republik Indonesia. Peraturan Pemerintah Nomor 22 Tahun 2015 Tentang Perubahan Atas Peraturan Pemerintah Nomor 60 Tahun 2014 Tentang Dana Desa yang Bersumber dari Anggaran Pendapatan dan Belanja Negara 2015.

[19] Agung W. Komunikasi Personal 2020.

[20] Rini. Komunikasi Personal 2020.

[21] Rakhmawati. Komunikasi Personal 2020.

[22] Kusworo D. Komunikasi Personal 2020.

[23] Widyanto. Komunikasi Personal 2020.

[24] Alamsyah N. Komunikasi Personal 2020.

[25] Syahroni. Komunikasi Personal 2020.

[26] Boedijono, Wicaksono G, Puspita Y, Bidhari SC, Kusumaningrum ND, Asmandani V. Efektifitas Pengelolaan Dana Desa Untuk Pembangunan Dan Pemberdayaan Masyarakat Desa Di Kabupaten Bondowoso. J Ris Manaj Dan Bisnis Fak Ekon UNIAT 2019;4:9-20. https://doi.org/10.36226/jrmb.v4i1.237.

[27] Zakariya. Budget Policy That Encourages Economic Growth and Village Empowerment. Int J Innov Creat Chang 2020;13:1726-37.

[28] Pemerintah Desa Wirokerten. Instrumen Pendataan Profil Desa Wirokerten. Bantul: Badan Pemberdayaan Masyarakat Kabupaten Bantul; 2017.

[29] Atmojo ME, Fridayani HD, Kasiwi AN, Pratama MA. Efektivitas dana desa untuk pengembangan potensi ekonomi berbasis partisipasi masyarakat di Desa Bangunjiwo. ARISTO Sos Polit Hum 2017;5:126-40. https://doi.org/10.24269/ars.v5i1.423.

[30] Sawitri D. Keikutsertaan Masyarakat Dalam Pengembangan Lokal (Studi Kasus: Pengembangan Desa di Jawa Barat). J Reg City Plan 2006;17:39-60.

[31] Fitriyani LY, Marita, Windyastuti, Nurahman RW. Determinants of Village Fund Allocation. J Akunt Multiparadigma 2018;9:526-39. https://doi.org/10.18202/jamal.2018.04.9031.

[32] Ferina IS, Burhanuddin, Lubis H. Tinjauan Kesiapan Pemerintah Desa Dalam Implementasi Peraturan Menteri Dalam Negeri Nomor 113 Tahun 2014 Tentang Pengelolaan Keuangan Desa (Studi Kasus Pada Pemerintah Desa Di Kabupaten Ogan llir). J Manaj Dan Bisnis Sriwij 2014;14:321-36. https://doi.org/10.29259/jmbs.v14i3.3991.

[33] Hambali IR, Niode IY. Improvement of Village Productive Economy Through Village Funds Financing. Int J Appl Bus Int Manag 2019;4:104-12. https://doi.org/10.32535/ijabim.v4i3.688. 